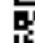

\title{
The Role of the Basal Core Promoter (BCP) and Precore Codon 28 Mutations in the Treatment Response to the Pegylated Interferon
}

\author{
Pegile-Interferon Tedavisine Yanitta Bazal Kor Promoter (BCP) ve Prekor Kodon 28 \\ Mutasyonlarının Rolü
}

\author{
Şükran KÖSE, Süheyla Serin SENGER, Gülsün ÇAVDAR, Pelin ADAR \\ Tepecik Education and Research Hospital, Clinic of Infectious Diseases and Clinical Microbiology, Izmir, Turkey
}

\begin{abstract}
Objective: Pegylated interferon has an important place in chronic hepatitis treatment and there are many factors affecting treatment response. Among these factors, studies on viral genomic mutations increase recently. In this study we aimed to determine the effects of precore and basal core promoter (BCP) mutations on the response to peg-interferon treatment treatment in patients received interferon treatment with the diagnosis of chronic hepatitis $\mathrm{B}$.

Materials and Methods: Seventy eight chronic hepatitis B patients were enrolled in the study. Before the treatment precore codon and BCP mutations were studied by Multiplex PCR and Reverse Hybridization Methods (Inno-Lipa HBV DR v2.Innogenetics, Belgium). Biochemical and virological response rates were calculated for patients treated with peg-interferon therapy for 48 weeks.

Results: Twenty two patients had precore codon 28 mutations, 10 patients had BCP (A1762/T1764) or BCP (T1762/A1764) mutations, 19 had precore codon 28 mutations with BCP mutations, and 27 patients had no mutations. Virological response rates in teh precore codon 28 mutation group were $68.1 \%, 80 \%$ in the $\mathrm{BCP}$ mutation group, and $73.7 \%$ in the group with both mutations, and $70.4 \%$ in the group with no mutations.

Conclusion: According to these results, although the presence of $\mathrm{BCP}$ mutations is an indicator of a better response to pegylated interferon treatment, it was not statistically significant. However, in order to demonstrate that it is effective in the response to interferon therapy, newer studies with much larger patients groups should be conducted. (Viral Hepatitis Journal 2014; 20(1): 19-22)
\end{abstract}

Key words: Hepatitis B, pegylated interferon, precore mutations
ÖZET

Amaç: Pegile interferon, kronik hepatit tedavisinde önemli bir yere sahiptir. Pegileinterferona tedavi yanıtını etkileyen birçok faktör bulunmaktadır. Bunlar arasında viral genomik mutasyonlarla ilgili yapılan çalışmalar son zamanlarda artmaktadır. Bu çalışmada, kronik hepatit B tanısıyla interferon tedavisi verilmiş hastalarda prekor ve bazal kor promoter (BCP) mutasyonlarının pegile interferon tedavisine yanıttaki etkilerini saptamayı amaçladık.

Gereç ve Yöntemler: Çalışmaya kronik hepatit B tanılı 78 hasta dâhil edildi. Tedavi öncesi prekor kodon ve BCP mutasyonları nested PCR yöntemiyle çalışıldı. Pegile interferon tedavisi 48 hafta süreyle uygulanan hastaların virolojik ve biyokimyasal yanıt oranları hesaplandı.

Bulgular: Hastaların 22'sinde prekor kodon 28 mutasyonu, 10'unda BCP (A1762) T1764) ya da BCP (T1762/A1764) mutasyonu, 19'unda prekor kodon 28 mutasyonu ile birlikte BCP mutasyonu saptanırken, 27 hastada herhangi bir mutasyona rastlanmadı. Virolojik yanıt oranları prekor kodon 28 mutasyonu saptanan grupta $\% 68,1$; BCP mutasyonu saptanan grupta \%80, her iki mutasyonun birlikte bulunduğu grupta $\% 73,7$; mutasyon saptanmayan grupta ise $\% 70,4$ olarak hesaplandı.

Sonuç: Bu sonuçlara göre BCP mutasyonlarının varlığı, pegile interferon tedavisine yanıtta daha iyi yanıt göstergesi olsa da, istatistiksel olarak anlamlı bulunmamıştır. Ancak interferon tedavisine yanıtta etkili olduğunun gösterilebilmesi için çok daha geniş hasta gruplarılla birçok yeni çalışma yapılmasının gerektiğini düşünmekteyiz. (Viral Hepatit Dergisi 2014; 20(1): 19-22)

Anahtar Kelimeler: Hepatit B, pegile interferon, prekor mutasyonları 


\section{Introduction}

Chronic hepatitis B virus (HBV) infection is an important health problem that can cause $25 \%-40 \%$ of the liver cirrhosis and hepatocellular carcinoma. Approximately 350 million people worldwide have chronic hepatitis B $(1,2)$.

The goal of treatment is to protect patients from complications of hepatitis B. Pegylated-interferon has an important place in the treatment of chronic hepatitis. Approximately one third of patients with interferon therapy develops $\mathrm{HBeAg}$ seroconversion (3). Pegylated-interferon, has an important role in the treatment of chronic hepatitis, there are many factors that affect response to therapy. These include the role of viral genomic mutations even if it is not clarified yet, although the studies on this subject are increasing recently.

Precore stop codon mutations blocking $\mathrm{HBeAg}$ expression without preventing HBV replication, aggravate liver disease and cause fulminant hepatitis $(4,5,6)$. The most frequent stop mutation in HBV precore side is located in G1896A. As a result of this precore mutation, codon 28 which is known as stop codon and thus the $\mathrm{HBeAg}$ synthesis is prevented $(7,8,9)$. While the precore mutation is rare in patients with genotype $A$, it is especially is more common in patients infected with genotype-D $(10,11)$. One of the other mutation groups affects the basal core promoter (BCP) region. The most common mutations in BCP are nt $1762(\mathrm{~A}-\mathrm{T})$ and 1764 (G-A). This mutation was first reported by Okamato et al (12). BCP mutations cause less transcription of RNA, while it does not affect significantly RNA transcription or translation of core proteins. The formation of these mutations resulted in an decrease the synthesis of $\mathrm{HBeAg}$ and viral load increase and they occur more often in patients with genotype-A, B and C (13).

In this study, we aimed to determine the effects of precore and BCP mutations on pegylated-interferon treatment response who followed in our hospital with a diagnosis of chronic hepatitis $B$ patients treated with pegylated interferon.

\section{Material and Methods}

Seventy-eight patients treated 48 weeks with pegylated interferon for chronic hepatitis B infection were included in the study. The inclusion criteria; >18 year old, being more than 6 monts of HBsAg positivity, HBV DNA $\geq 105$ copies / mL in HBeAg positive patients, HBV DNA $\geq 104$ copies / $\mathrm{mL}$ in HBeAg negative patients, patients who used pegylated interferon at least twelve months, patients whose serum HBV DNA levels measured before, 3,6 and 12 months of treatment and cases with HBV precore and BCP mutations studied before the treatment. Exclusion criteria; who stopped the treatment before 12 months, pregnants, transplant patient, patients who had major depression, untreated hyperthyroid, uncontrolled hypertension, heart disease, diabetes mellitus, autoimmune diseases, decompensated liver disease and renal failure. Before the treatment, serum HBsAg, anti$\mathrm{HBs}, \mathrm{HBeAg}$, anti-HBe serologic indicators were tested with EIA (Liaison, Diasorin, Italy) method in patient serum. Each patient was underwent liver biopsy and then staged by Knodell staging scoring system. HBV-DNA and liver function tests were performed before treatment, 12, 24, 36 and 48 weeks of the treatment. Real time PCR method (COBAS Ampliprep / COBAS Taqman 48, Roche, Branchburg, NJ, USA) for HBV-DNA test was used.
HBV precore and BCP mutations were studied before the treatment by multiplex PCR and reverse hybridization methods (Inno-Lipa HBV DR v2. Innogenetics, Belgium). HBV-DNA <2000 $\mathrm{IU} / \mathrm{mL}$ at 6 months of the treatment is accepted as virological response criteria and alanine aminotransferase (ALT) normalization is accepted as biochemical response (14).

Chi-square test was used for statistical analysis of mutations detected and undetected virologic response according to the state group.

\section{Results}

Forty-nine $(62.8 \%)$ of the 78 patients were males, mean age was 38.8 year (range:20-58). All patients in the study were infected with hepatitis $B$ genotype $D$. The number of the patients with pc codon 28 mutation, BCP (A1762/T1764) or BCP (T1762/A1764) mutation, pc codon 28 mutation with the BCP mutation were 22, 10 and 19, respectively. No mutation was determined in 27 patients.

In 22 patients with precore codon 28 mutation, mean HBVDNA, mean ALT and virological response rate were $1,8 \mathrm{E}+7 \mathrm{IU} /$ $\mathrm{mL}, 57,5 \mathrm{IU} / \mathrm{dL}$ and $68,1 \%$, respectively at the beginning of the treatment. The biochemical response rate was $72,7 \%$ at the end of the treatment. In 10 patients with BCP (A1762/T1764) or (T1762/A1764) mutations, mean HBV-DNA, mean ALT and virological response rate were $3,9 \mathrm{E}+5 \mathrm{lU} / \mathrm{mL}, 36,4 \mathrm{lU} / \mathrm{dL}$ and $80 \%$, respectively at the beginning of the treatment. In 19 patients with precore codon 28 mutation and BCP mutations, mean HBV-DNA, mean ALT, virological response rate and biochemical response rate were $6,7 \times 10^{7} \mathrm{IU} / \mathrm{mL}, 64,4 \mathrm{U} / \mathrm{L}, 73,7 \%$ and $78,9 \%$, respectively at the beginning of the treatment. In 27 patients with no mutation, mean HBV-DNA, mean ALT, virological response rate and biochemical response rate were $4,4 \times 10^{7} \mathrm{IU} / \mathrm{mL}, 68,6 \mathrm{IU} / \mathrm{L}$, $70,4 \%$ and $74,1 \%$, respectively at the beginning of the treatment. All results were shown in (Table1).

According to the results obtained BCP presence of mutations, in response to treatment with pegylated interferon better response indicator, though, were not statistically significant. The presence of precore mutation in precore codon 28 group with virologic response was not statistically significant.

\section{Discussion}

The main goals in the treatment of chronic HBV are reduce or stop the replication of HBV and prevent to develop the complications such as cirrhosis, liver failure and hepatocellular carcinoma. For this purpose, the one of the main target is HBV-DNA reduction or disappearance $(15,16)$. Among the drugs currently used in the treatment of chronic hepatitis $B$, the pegylatedinterferon has an important role. In many studies conducted with pegylated-interferon treatment showed that there are some factors affecting the treatment response. These includes the initial ALT and HBV-DNA levels, genotype, age, sex and HBeAg status $(17,18,19)$. -Genetic changes are thought to play an important role in the natural course of HBV infection. These mutations may also influence the development liver cancer, chronic liver disease and of fulminant hepatitis. First identified and the most emphasized HBV mutations are precore / core mutations (20). Studies have found higher 


\begin{tabular}{|l|c|c|c|c|}
\hline Table 1. Baseline treatment characteristics and response rates of patients according to the mutation status \\
\hline Characteristics & $\begin{array}{c}\text { Precore mutation group } \\
(\mathbf{n = 2 2})\end{array}$ & $\begin{array}{c}\text { BCP mutation group } \\
(\mathbf{n = 1 0})\end{array}$ & $\begin{array}{c}\text { Precor Codon 28+BCP } \\
\text { mutation group (n=19) }\end{array}$ & $\begin{array}{c}\text { Undetected mutation } \\
\text { group (n=27) }\end{array}$ \\
\hline Age & 37.9 & 39.3 & 39.1 & 38.7 \\
\hline Gender (male/female) & $11 / 11$ & $8 / 2$ & $14 / 5$ & $16 / 11$ \\
\hline ALT (U/L) & 57.5 & 36.4 & 64.4 & 68.6 \\
\hline HBV-DNA (IU/mL) & $1.8 \mathrm{E}+7$ & $3.9 \mathrm{E}+5$ & $6.7 \mathrm{E}+7$ & $4.4 \mathrm{E}+7$ \\
\hline HAI & 10.1 & 9.2 & 9.6 & 11.5 \\
\hline Genotype & $\mathrm{D}$ & $\mathrm{D}$ & $\mathrm{D}$ & $\mathrm{D}$ \\
\hline HBeAg (+) & 4 & 2 & 4 & 9 \\
\hline Virological response (\%) & 68.1 & 80 & 73.7 & 70.4 \\
\hline Biochemical response (\%) & 72.7 & 80 & 78.9 & 74.1 \\
\hline
\end{tabular}

prevalence of precore mutation in patients with $\mathrm{HBeAg}$ positive and showed that these mutations increase the risk of persistent hepatitis and liver cirrhosis (21). In USA studies performed in adults infected with chronic $\mathrm{HBV}$, the prevalence of this mutation ranges from 20\%-95\% (22). In our country, Arslan et al. did not detect any precore / core mutations of 51 HBV DNA-positive chronic hepatitis B patients (23). Today, the effects of these mutations in the antiviral response to treatment are not clear. The most recent studies showed that the patients have no precore mutation chain before treatment with interferon alpha, had better treatment results $(24,25)$. Unlikely, we found that virological response rates were similar in groups with or without precore mutation.

The core mutation affect BCP which includes c1742-c1849 nucleotide ad cause decreased transcriptional precore and core mRNA. BCP mutation usually is located in Nt 1744-1804 (21). In some studies with BCP mutations found that these mutations were associated with increased viral replication and viral load, suppressed expression of HBeAg. However, other studies were found no association with viral load level (26-29). Moreover, it has been considered that BCP double mutations increase viral replication, fulminant liver failure and hepatocellular carcinoma by upregulating pregenomic RNA (30). In this respect, BCP mutations have an important role to follow-up of chronic HBV. Although there is not much study on the effects of the mutations on the pegylated interferon response, it has been reported that especially the T1762, A1764 were advantage in response to pegylated interferon therapy $(31,32)$. Similarly, in our study the virological response rate was higher in groups with BCP mutations than in the group have no mutations, but there was no statistically significant differences between the groups $(p>0.05)$.

According to the results obtained BCP presence of mutations, in response to treatment with pegylated interferon better response indicator, though, were not statistically significant. The presence of precore mutation in precore codon 28 group with virologic response was not statistically significant. To clarify the effects of both the precore codon 28 and BCP double mutations on the response to pegylated interferon, the new studies with large patients groups are needed.

\section{Conflict of interest: None declared.}

\section{References}

1. Ganem D, Prince AM. Hepatitis B virus infection-natural history and clinical consequences. N Engl J Med. 2004; 350: 11181129.

2. Lee WM. Hepatitis B virus infection. N Engl J Med 1997; 337: 1733-1745.

3. Lau GK1, Piratvisuth T, Luo KX, Marcellin P, Thongsawat $S$, Cooksley G, Gane E, Fried MW, Chow WC, Paik SW, Chang WY, Berg T, Flisiak R, McCloud P, Pluck N; Peginterferon Alfa-2a HBeAg-Positive Chronic Hepatitis B Study Group. Peginterferon Alfa-2a, lamivudine, and the combination for HBeAg-positive chronic hepatitis B. N Engl J Med. 2005; 352: 2682-2695.

4. Papatheodoridis GV, Hadziyannis SJ. Diagnosis and management of pre-core mutant chronic hepatitis B. J Viral Hepat. 2001; 8: 311-321.

5. Omata M, Ehata T, Yokosuka O, Hosoda K, Ohto M. Mutations in the precore region of hepatitis $B$ virus DNA in patients with fulminant and severe hepatitis. N Engl J Med. 1991; 324: 1699-1704.

6. Friedt $M$, Gerner P, Lausch E, Trubel H, Zabel B, Wirth S. Mutations in the basic core promotor and the precore region of hepatitis B virus and their selection in children with fulminant and chronic hepatitis B. Hepatology. 1999; 29: 1252-1258.

7. Akahane $Y$, Yamanaka T, Suzuki H, Sugai $Y$, Tsuda F, Yotsumoto S, Omi S, Okamoto H, Miyakawa Y, Mayumi M. Chronic active hepatitis with hepatitis B virus DNA and antibody against e antigen in the serum. Disturbed synthesis and secretion of e antigen from hepatocytes due to a point mutation in the precore region. Gastroenterology. 1990; 99: 1113-1119.

8. Brunetto MR1, Giarin MM, Oliveri $F$, Chiaberge $E$, Baldi $M$, Alfarano A, Serra A, Saracco G, Verme G, Will H. Wild-type and e antigen-minus hepatitis $B$ viruses and course of chronic hepatitis. Proc Natl Acad Sci U S A. 1991; 88: 4186-4190.

9. Carman WF1, Jacyna MR, Hadziyannis $S$, Karayiannis $P$, McGarvey MJ, Makris A, Thomas HC. Mutation preventing formation of hepatitis $B$ e antigen in patients with chronic hepatitis B infection. Lancet. 1989; 2: 588-591.

10. Rodriguez-Frias F, Buti M, Jardi R, Cotrina M, Viladomiu L, Esteban R, Guardia J. Hepatitis B virus infection: precore mutants and its relation to viral genotypes and core mutations. Hepatology. 1995; 22: 1641-1647.

11. Grandjacques $C 1$, Pradat $P$, Stuyver $L$, Chevallier $M$, Chevallier $P$, Pichoud C, Maisonnas M, Trépo C, Zoulim F. Rapid detection of genotypes and mutations in the pre-core promoter and the precore region of hepatitis $B$ virus genome: correlation with viral persistence and disease severity. J Hepatol. 2000; 33: 430-439. 
12. Okamoto $H$, Tsuda F, Akahane $Y$, Sugai $Y$, Yoshiba M, Moriyama K, Tanaka T, Miyakawa Y, Mayumi M. Hepatitis B virus with mutations in the core promoter for an e antigen-negative phenotype in carriers with antibody to e antigen. J Virol 994; 68: 8102-8110

13. Hunt CM1, McGill JM, Allen MI, Condreay LD. Clinical relevance of hepatitis $B$ viral mutations. Hepatology 2000; 31: 1037-1044.

14. European Association for the Study of the Liver (EASL) Guidelines: Journal of Hepatology 2009; 50: 227-242.

15. Liaw YF, Leung N, Guan R, Lau GK, Merican I, McCaughan G, Gane E, Kao JH, Omata M; Asian-Pacific consensus update working party on chronic hepatitis B: Asian-Pacific consensus statement on the management of chronic hepatitis B: a 2005 update 2005: 25: 472-489.

16. Marcellin P1, Lau GK, Bonino F, Farci P, Hadziyannis $S$, Jin R, Lu ZM, Piratvisuth T, Germanidis G, Yurdaydin C, Diago M, Gurel S, Lai MY, Button P, Pluck N; Peginterferon Alfa-2a HBeAgNegative Chronic Hepatitis B Study Group. Peginterferon alfa-2a alone, lamivudine alone, and the two in combination in patients with HbeAgnegative chronic hepatitis B, N Engl J Med 2004;351:1206-1217.

17. Flink HJ, van Zonneveld M, Hansen BE, de Man RA, Schalm SW, Janssen HL; HBV 99-01 Study Group. Treatment with Peg-interferon alpha-2b for HBeAg-positive chronic hepatitis $\mathrm{B}$ : HBsAg loss is associated with HBV genotype. Am J Gastroenterol 2006; 101: 297-303.

18. Bonino F1, Marcellin P, Lau GK, Hadziyannis S, Jin R, Piratvisuth T, Germanidis G, Yurdaydin C, Diago M, Gurel S, Lai MY, Brunetto MR, Farci P, Popescu M, McCloud P; Peginterferon Alfa-2a HBeAg-Negative Chronic Hepatitis B Study Group. Predicting response to peginterferon alpha-2a, lamivudine and the two combined for HBeAg-negative chronic hepatitis B. Gut. 2007; 56: 699-705.

19. Tekeli A. Hepatit $B$ virüsünde mutasyon ve önemi. Tabak F, Balık I, Tekeli E, ed. Viral Hepatit 2005'te. Ankara: Viral Hepatitle Savaşım Derneği. 2005; s:160-168.

20. Chu CM, Yeh CT, Lee CS, Sheen IS, Liaw YF. Precore stop mutant in $\mathrm{HBeAg}$-positive patients with chronic hepatitis $\mathrm{B}$ : Clinical characteristics and correlation with the course of HBeAg-to-AntiHBe seroconversion. J Clin Microbiol 2002; 40: 16-21.

21. Gunther S, Fischer L, Pult I, Sterneck M, Will H. Naturally occurring variants of hepatitis B virus. Adv Virus Res 1999; 52 : 125-137.
22. Seo $Y$, Yoon $S$, Hamano $K$, Nakaji $M$, Yano $Y$, Katayama $M$, Ninomiya T, Hayashi $Y$, Kasuga M. Response to interferonalpha in chronic hepatitis B with and without precore mutant strain detected by mutation site-specifi c assay. J Clin Gastroenterol 2004; 38: 460-464.

23. Arslan U, Tuncer I, Fındık D, Ural O. HBeAg negatif, anti$\mathrm{HBe}$ pozitif kronik hepatit B olgularında prekor/kor bölge mutasyonlarının ve genotip dağılımlarının değerlendirilmesi. Infeksiyon dergisi 2008; 22:123-129.

24. Buckwold VE, Xu Z, Chen M, Yen TS, Ou JH. Effects of a naturally occurring mutation in the hepatitis $B$ virus basal core promoter on precore gene expression and viral replication. J Virol. 1996; 70: 5845-5851.

25. Sonneveld MJ, Rijckborst V, Zeuzem S, Heathcote EJ, Simon K, Senturk H, Pas SD, Hansen BE, Janssen HL. Presence of precore and core promoter mutants limits the probability of response to peginterferon in hepatitis $\mathrm{B}$ e antigen-positive chronic hepatitis B. Hepatology. 2012; 56: 67-75.

26. Scaglioni PP, Melegari M, Wands JR. Biologic properties of hepatitis B viral genomes with mutations in the precore promoter and precore open reading frame. Virology. 1997; 233: 374-381.

27. Yoo BC, Park JW, Kim HJ, Lee DH, Cha YJ, Park SM. Precore and core promoter mutations of hepatitis $B$ virus and hepatitis $B$ e antigen-negative chronic hepatitis B in Korea. J Hepatol. 2003; 38: 98-103.

28. Pang A, Yuen MF, Yuan HJ, Lai CL, Kwong YL. Real-time quantification of hepatitis $\mathrm{B}$ virus core-promoter and pre-core mutants during hepatitis $\mathrm{E}$ antigen seroconversion. J Hepatol. 2004; 40: 1008-1017.

29. Chen WN, Oon CJ. Mutations and deletions in core promoter and precore stop codon in relation to viral replication and liver damage in Singaporean hepatitis B virus carriers. Eur J Clin Invest. 2000; 30: 787-792.

30. Jammeh S, Tavner F, Watson R, Thomas HC, Karayiannis P. Effect of basal core promoter and pre-core mutations on hepatitis B virus replication. J Gen Virol. 2008; 89: 901-909.

31. Agdamag DM1, Kageyama S, Leaño PS, Solante RM, Telan EF, Que ER, Ichimura H. Prediction of response to treatment of chronic hepatitis $B$ with pegylated interferon in the Philippines. Med Virol. 2010; 82: 213-219.

32. Tangkijvanich $P$, Komolmit $P$, Mahachai $V$, Sa-nguanmoo $P_{1}$ Theamboonlers A, Poovorawan Y. Low pretreatment serum HBsAg level and viral mutations as predictors of response to PEG-interferon alpha-2b therapy in chronic hepatitis B. J Clin Virol. 2009; 46: 117-123. 